NEJE

25,1

26

Received 31 July 2020 Revised 28 April 2021 18 June 2021

8 July 2021

Accepted 14 July 2021

\title{
Architectural dimensions of socially driven venture capital firms: social innovation in the capital markets
}

\author{
Raymond J. Jones \\ Management, Stephen F Austin State University, Nacogdoches, Texas, USA, and \\ Manjula S. Salimath \\ G. Brint Ryan College of Business, University of North Texas, Denton, Texas, USA
}

\begin{abstract}
Purpose - Private equity and venture capital (VC) firms in the capital markets sector invest capital with the primary goal of delivering economic value. However, some firms in the capital markets sector have started to shift this focus to create (i.e. invest in) social value. More specifically, traditional VC firms are starting socially oriented funds, while other firms have emerged to focus solely on investments in social enterprises. These VC firms are contributing to an interesting paradox - performance metrics are not measured by profit alone but also by social innovation. From an architectural perspective, the authors examine the implications of internal design, i.e. how specific strategic and structural factors influence the financial performance of VC firms with a social orientation to determine if these firms really can "do well and do good."

Design/methodology/approach - Social orientation was determined by content analysis of mission statements of the VC firms. Firm strategies, structures and performance were sourced from secondary data. A moderated mediation model was used to test relationships.

Findings - Results suggest that (1) socially responsible VC firms adopt distinct foci of social investing that directs their strategic orientation and (2) these various foci have vastly differing effects on the firm's overall performance, strategic decisions made and the architecture of their structural design.

Originality/value - This study is among the first to explore socially responsible VC architectural dimensions, with implications for firm design based on blended measures of success.
\end{abstract}

Keywords Social innovation, Venture capital, Strategy, Organizational structure, Performance

Paper type Research paper

\section{Introduction}

Socially responsible investing (SRI) is a fast-growing segment of the financial service industry involving over $\$ 17.1$ trillion in professionally managed assets in the USA alone (Social Investment Forum, 2020). SRI is as a process of integrating personal values and societal concerns into investment decision-making and impactful type of social innovation (Schueth, 2003). SRI embodying ethical values, environmental protection, improved social conditions and good governance has attracted the interest of individual and private investors, as well as academics (Revelli and Viviani, 2015). Not unlike conventional types of investments, SRI applies a set of investment screens to select or exclude assets (Renneboog et al., 2008). Notwithstanding the economics of this approach, the social values embodied in

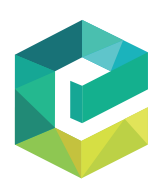

New England Journal of Entrepreneurship Vol. 25 No. 1,2022 pp. $26-47$

Emerald Publishing Limited 2574-8904

DOI 10.1108/NEJE-07-2020-0027
(C) Raymond J. Jones and Manjula S. Salimath. Published in New England Journal of Entrepreneurship. Published by Emerald Publishing Limited. This article is published under the Creative Commons Attribution (CCBY 4.0) license. Anyone may reproduce, distribute, translate and create derivative works of this article (for both commercial and non-commercial purposes), subject to full attribution to the original publication and authors. The full terms of this license may be seen at http://creativecommons. org/licences/by/4.0/legalcode

This manuscript is based on the first author's doctoral dissertation (Jones, 2013). 
SRI have become increasingly popular due to demands for products that positively affect their social and environmental stakeholders (Alsmadi, 2007). These pressures stem from regulatory structures, governmental agencies, laws, courts, professions, scripts and other societal and cultural practices (Bull, 2008). Since the economic effectiveness of such an investment strategy is a concern, given the tensions between doing well and doing good (Hamilton et al., 1993), a primary focus of past research has been on identifying whether these SRI practices can produce the same level of financial performance as traditional investment strategies (Kurtz, 1997; Hoepner and McMillan, 2009; Capelle Blancard and Monjon, 2014).

More recently the venture capital (VC) industry has started to follow suit. Traditionally, VC firms raise funds from numerous investors and then invest those funds in private companies with the purpose of achieving significant investment returns (Dimov et al., 2007). Those investing in entrepreneurial firms whose missions have a socially or environmentally related orientation and/or impact are labeled as a socially responsible VC (Randjelovic et al., 2003).

In this study, we link SRI to the larger process of social innovation as it is related to the practices that enable conditions for addressing complex social issues (Adams and Hess, 2011). That is, it adheres to the view that problems and solutions are larger than one individual or organization (Phills et al., 2008). It involves the development of capacities through investment in resources. As part of this capacity build up, social innovation adopts an investment model rather than focusing on deficit. This asset model enables focus on the actual assets and the empowerment of the organizations, communities or individuals closest to the problem rather than just focusing on a quick fix to the problem. Here, we see a direct link to why SRI through VC funding supports this model of social innovation as they are supporting those organizations closest to the issues.

Emerging research on "socially responsible VC" raises several questions related to social criteria used for investment decisions, with the most widely used Environmental, Social, Governance (ESG) criteria are, and the relationship between ESG engagement and return on investment (Meles, 2021). Despite a handful of studies examining the nature and strategies of these blended value oriented VC firms (Randjelovic et al., 2003; Miller and Wesley, 2010; Rajan et al., 2014), there is a significant gap in understanding the role played by VC funding in advancing social innovation (Lerner, 2009).

The ability to select a relevant strategy and match it with the appropriate structure characterizes effective firm strategic processes (Olson et al., 2005). Similarly, identifying how socially innovative organizations design their organizational structures and strategies becomes essential for understanding their performance (especially regarding the paradox of achieving economic and social goals). Thus, our primary research question is What is the role of strategic and structural factors in the performance of socially innovative venture capital firms' engagement in socially responsible investing (henceforth socially responsible VC)?

\section{Architecture and organizational design}

Theoretical support for examining social innovation at the organizational and business unit level from an architectural standpoint is drawn from Chandler's (1969) design school. This framework highlights how strategy emerges from a planned and explicit mission based on certain goals that are necessary to focus efforts and define the organization (Mintzberg, 1990). Design therefore represents an interesting heuristic to explore the concept of SRI as a social innovation (Mulgan et al., 2007; Mulgan, 2010).

Structure helps to guide the use of strategy, indicate how to compare actual and expected results and suggest actions to take to improve performance that is below expectations (Kaplan and Norton, 2001). New organizational forms may originate out of the necessity to adapt to changes in the environment (Tushman and Romenlli, 1985). This strategic choice perspective allows for adaptation of organizational form by managers, environmental and 
NEJE

25,1

contextual factors. The existing capital market sector logics support investments with a high potential for returns but do not support goals outside that financial norm creating significant tensions for socially oriented firms.

With the new institutional logic of SRI, individuals and organizations have started to focus on socially responsible investments to address social issues (Thompson et al., 2000) paired with traditional financial outcomes (Carroll, 1991). Firm structure and strategy are relevant to organizational-level performance (Miller, 1986) even in socially innovative organizations. Hence, this investigation is concerned with the importance of both strategy and structure to optimize efficiency, not on one leading the other.

\section{Theoretical model and hypotheses}

Figure 1 provides a visual representation of the theoretical model for the study. The following sections elaborate on each variable in the model and the relationships therein.

\section{Social mission and performance}

Having a mission is essential to the strategy making process and can have direct bearing on performance outcomes (Pearce and David, 1987; Bright, and Godwin, 2010). While its behavioral benefits are important (individual motivation toward common goals), missions also provide several benefits to organizational performance (Bart and Baets, 1998). They impact performance because they sharpen the organization's focus and lead to wiser use of resources, e.g. giving the firm strategic direction (Wickham, 1997).

When examining social innovation in the VC industry, prior research indicates that SRI is profitable (Kurtz, 1997; Kempf and Osthoff, 2007). It is therefore possible that the positive relationship between financial performance and SRI will also hold in the context of the VC market. Thus:

H1. An explicit social mission will have a positive relationship with the performance of a social VC firm.

\section{Social mission and organizational strategies}

While social missions may have a direct relationship with organizational performance, it is also likely that social missions guide organizational strategies. A clear social mission

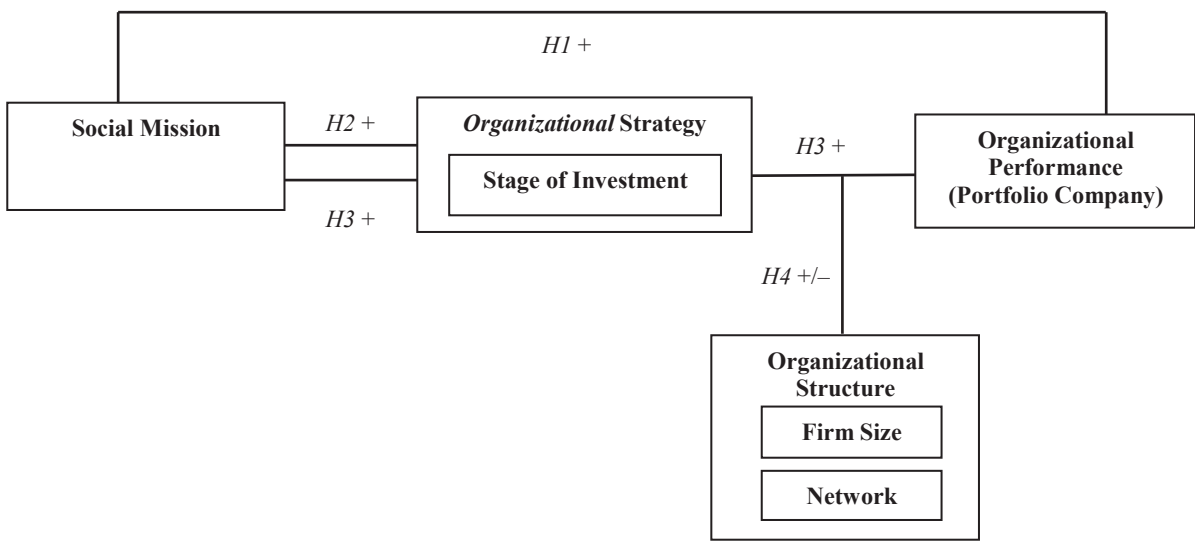

Figure 1.

Theoretical model 
provides the deliberateness required to define and set boundary conditions that are present in high-performing organizations and successful social innovations (Ridley-Duff, 2008).

As social innovation attempts to identify new alternatives to existing conditions, it is likely that these novel ideas will emerge in the realm of new products/services or developing markets. Social innovation is built on the idea of finding and creating new models (Goyal et al., 2016). Existing products/services may provide less risk for the both VC firms and their stakeholders but may not deliver (social) values that socially oriented VCs seek. Although social value based on ESG strategies in later-stage investments can also occur, more value (social and financial) is identifiable in earlier stages, offering significant opportunity for growth and scalability (Meles, 2021). Additionally, a global increase and rise of new social enterprises (Argarwal et al., 2018) expands the opportunity for investing in social value at the early stages. Socially responsible VCs seek new and socially related enterprises as a valueadded component, while VCs without a social value focus would characterize socially related enterprises as carrying more risk and as a potential liability (Randjelovic et al., 2003). Therefore, socially responsible VCs will focus their investment decisions toward earlier-stage investments which enable them to realize their social goals. Thus:

H2. An explicit social mission will have a positive relationship with early stage investments.

\section{Organizational strategies and performance}

$\mathrm{VC}$ is often demarcated by the investor, the risk propensity and the management of the portfolio. Institutional and individual investors have varying motives that affect capital allocation and portfolio diversification. Typically, portfolios are optimally designed to balance risk and rewards by allocating capital across various investment types (Cumming and Johan, 2007). From the institutional investor's perspective, all investments should have the objective of gaining maximum returns for an appropriate level of risk but that does not necessarily exclude social concerns. Therefore, if a socially responsible VC fund can provide an appropriate level of risk and return ratio, this alternative investment could align with conventional justifications for all investment decisions (Guyatt, 2006).

Strategies often follow an a priori goal (Mintzberg and Waters, 1985) or mission (Slater et al., 2006). Socially innovative organizations will seek opportunities that are consistent with their social mission; hence, they will inevitably adopt organizational strategies that align with their social mission. As the content of strategy is generated from organizational goals and missions (Mintzberg, 1990), it is operationally transmitted to organizational performance (Venkatraman, 1989). Hence, firms select strategies that align with the organization's mission to achieve superior performance.

This transmission relationship implies that organizational strategy is an important mediator between mission and performance. As previously discussed, social missions are best executed via early stage investment strategies and are more likely to lead to superior performance. Thus:

H3. Organizational strategy (early stage investments) will mediate the relationship between the social missions and firm performance.

\section{Organizational strategy, structure and performance}

Researchers posit that strategy is not universally superior (Venkatraman, 1989) and that other factors, such as environment, organizational context or structure interact with organizational strategies to influence performance, i.e. organizational context is important (Harringan, 1983; Ginsberg and Venkatraman, 1985).

Structural aspects of an organization such as size and network affect the performance of both new and established organizations (Sacks, 2002). Structure is viewed as interaction and
Architectural dimensions of social VC firms 
NEJE

25,1

transmission variables, since it helps to realize organizational goals (Mintzberg, 1973). Organizations also build strong networks to increase access to resources, ideas and even new opportunities (Gulati, 1998). Thus, structural components are relevant for both nascent and established organizations.

Other factors (age, size and network) can impact the ability of firms to diffuse social innovations and affect firm success (Kaplan and Schoar, 2005).

Size

The size of the VC firm typically refers to the amount of capital the VC has available to invest (Dimov and Milanov, 2010). Size is relevant to performance - when more capital is available, there is more potential to invest in diverse and potentially high growth companies. Averitt (1968) posits that large, established firms experience different economic processes than smaller, less dominant ones in any industry. While larger organizations may be able to benefit from access to resources and insulation from market competition, they suffer from inertia and may be slow to adapt to environmental changes (Kelly and Amburgey, 1991). Smaller organizations, on the other hand, can be more responsive to environment shifts, rapidly adapting their strategies and operations to take advantage of the market (Smith et al., 1989). VC researchers reveal that while increases in size are important and positively relate to performance increase, the relationship is concave (Kaplan and Schoar, 2005; Hochberg et al., 2007). There is a point beyond which an organization can become too large and performance starts to decline. Thus:

H4a. Firm size will moderate the relationship between strategy (early stage investments) and firm performance such that the relationship is curvilinear.

\section{Networks}

A socially responsible VC's network is significant not only for performance but also for the support and diffusion of social innovation. Networks facilitate reputation development (a key factor in $\mathrm{VC}$ performance), enable access to information (new opportunities) and access to capital (Abell and Nisar, 2007; Dimov and Milanov, 2010).

Networks are a prominent feature in the VC industry as better-quality relationships and more influential network positions offer greater investment opportunity sets and access to information, essential to VC performance (Lindsey, 2008). VCs tend to syndicate (i.e. co-invest) with other VCs rather than investing alone (Lerner, 1994). They network with other VCs and service providers (patent lawyers, bankers, etc.) to make their portfolio companies succeed (Gorman and Sahlman, 1989).

Syndicates are a natural starting point in the examination of VC networks because they are easy to observe, and they affect the two main drivers of a VC's performance, namely, the ability to source high quality deal flow (i.e. select promising companies) and the ability to nurture investments (i.e. add value to portfolio companies) (Dimov and Milanov, 2010). In addition, networks are a key success factor in the capacity building and collaboration necessary to support scalability of social innovations (Bhatt and Altinay, 2013). Thus:

$H 4 b$. A VC firm's network will moderate the relationship between strategy (early stage investments) and firm performance such that when the network is larger, firm performance will increase.

\section{Methodology \\ Data}

Data on VC firms were obtained from the ThomsonOne Private Equity (PE) Database. The PE database is one of the most commonly used archival data sources for VC research in both finance 
and management literature (Kaplan et al., 2002). It is based on both self-reported information and secondary data (i.e. press releases and other news media). These data include demographical and historical background information on the VC firm, funds they manage or currently participating in, financing round information, amount of investment of all participating VCs, information on the sources of financing for each fund, as well as outcomes of the portfolio companies that received VC (i.e. went public, were acquired, shut down, still active investments).

VC firms was operationalized following criteria from the National Venture Capital Association's (NVCA) methodology and categorization on what a VC is and was used to search the ThomsonOne PE database. NVCA's categorization differs from the complete set of equity investments found in the ThomsonOne PE database. The ThomsonOne database includes data on any equity investment or financing round, which may or may not have been from a VC firm specific, applying the NVCA's criteria to classify VCs effectively. Second, similarly, firms were not restricted geographically, and data were drawn from firms that invest in the USA and internationally. Third, the sample was not limited to privately held VC firms. Many VC funds are connected to banks, corporations and governments. Fourth, as socially responsible VC is relatively recent (within the last 17 years, Randjelovic et al., 2003), it was important to capture newer VC firms to prevent the risk of a limited sample size. Therefore, no limitation was imposed on the time period. The sample was restricted to those VC firms that have an explicit mission. Finally, since this study is concerned with for-profit entities, care was taken to exclude nonprofit VC firms.

An initial set of 655 firms were identified by the NVCA search criteria. A total of 245 firms were excluded from the initial set of 655 firms as they did not fit within the inclusion criteria (e.g. no accessible information via the Internet, no mission statement, no longer active, etc.). In addition, VC firms that were over four standard deviations from the mean were considered as outliers and removed from the sample for analysis (Hair et al., 2009). This process resulted in a final sample of 381 relevant VC firms.

The sample primarily consisted of private equity VC firms $(82.2 \%)$, with the remainder affiliated with corporations $(6 \%)$, banks $(2.1 \%)$, governments $(3.9 \%)$ or other affiliations $(3.9 \%)$. The sample consisted predominantly of US-based VC firms $(79.8 \%)$. The average age of the firms was approximately 17 years from their first investment (i.e. vintage year). The average size of the firm, as measured by the amount of committed capital since firm inception, was over $\$ 529 \mathrm{~m}$; with the smallest firm having $\$ 105$ thousand and largest having over $\$ 8 \mathrm{bn}$ in committed capital. On average, VC firms invested in almost 91 portfolio companies, with $\$ 5.8 \mathrm{~m}$ invested per company. While $79.8 \%$ of the sample was US-based firms, there was significant amount of capital being invested internationally. An average of $\$ 489 \mathrm{~m}$ was invested internationally, with some firms investing in 40 different countries.

After VC firms were selected, the next step was to collect firm mission statements (or other representative statements where necessary), which were a formal declaration of the firm's strategic orientation. Currently, there is no internal search criterion in the database for socially responsible VC firms, and externally, the available lists of socially responsible VCs were limited in accuracy and completeness.

\section{Measures}

Social mission (firm socialness). A mission defines the broad outline for an organization's strategy (Slater et al., 2006). As this investigation is focused on socially innovative VC firms, a key factor to select the sample was whether the organization's mission explicitly included language related to a social orientation. However, as firms without a mission may still engage in socially innovative investment strategy, and firms with a mission that is not socially oriented may still invest in some social enterprises to diversify their overall portfolio strategy content analysis was then utilized to identify the degree to which the firm's mission statement 
NEJE

25,1

was related to social innovation, as part of the collection of firm mission statements (or other representative statements where necessary) (Ingenhoff and Fuhrer, 2010). Representative statements included mission, vision, philosophy, strategy statements or general statements describing the firm (often labeled "About Us") and other statements, which included letters and quotes from the managing partner, descriptive taglines from the firm website and social responsibility statements.

In line with prior research (Doucet and Jehn, 1997; Emrich et al., 2001; Short et al., 2010), a single measure of social mission was created by combining all the words from the key word lists for each separate dimension. The ensuing single dictionary was used in the DICTION software to create a single social mission measure. Analysis was conducted using both the combined and each separate dimensional measure of social mission to identify any disparity between a multidimensional and unidimensional construct of social mission.

There was considerable variance in the length of mission statements (mean $=67$ words, minimum $=2$ words, maximum $=402$ words). To control for the wide discrepancy in text length, the detected social investing construct words were standardized by dividing it by the total number of words found in the text, which was used as a measure of socialness. This control method follows other content analytic studies when text lengths vary considerably (i.e. Doucet and Jehn, 1997; Emrich et al., 2001).

Organizational strategy (stage of investment). VC firms operate in different industries and focus on various stages of investment. The ThomsonOne PE database provides information on stage of investment as an aggregate for each VC firm based on their total investments as well as for each fund and portfolio company. Stage of investment was measured as a continuous variable and calculated as the ratio of total investment amount in each stage (i.e. seed, early, expansion, late) (Lindsey, 2008; Hus, 2006; Hochberg et al., 2007).

$$
\begin{gathered}
\text { Stage of Investment }=\frac{\text { Total Amounted Invested in Early and Seed Stage }}{\text { Total Amount Invested }} \\
\text { Stage of Investment }=\frac{\text { Total Amounted Invested in Expansion Stage }}{\text { Total Amount Invested }} \\
\text { Stage of Investment }=\frac{\text { Total Amounted Invested in Late Stage }}{\text { Total Amount Invested }}
\end{gathered}
$$

\section{Organizational structure}

Size. In the VC industry, size often depends on the total amount of committed capital. Thus, following prior methodology, VC firm size is measured as the total amount of committed capital investments (Lerner, 1994; Gompers and Lerner, 1999; Hochberg, et al., 2007; Dimov and Milanov, 2010).

VCSize $=$ the total amount of committed capital over the life of the firm

Following recommendations by Lerner (1994), size was categorized by quartiles using zscores $(z=$ actual size - average size/standard deviation). Once quartiles were identified, a new size variable was created and coded from 0 to 3 to represent the four quartiles.

Network. The term used for a VC network is syndicate (Lerner, 1994) and includes current and past investments with other VCs. A VC draws on this network in both pre- and postinvestment stages.

Following Hochberg et al. (2007), Lindsey (2008) and Hsu (2006), a simplified count was used to determine the relative importance of each firm's network. The database provides information on the co-investors for each investment as well as identifying the lead investor 
for each deal. This methodology captures different aspects of a VC firm's network: (1) the number of VCs with which it has a relationship, as a proxy for the information, deal flow, expertise, contacts and pools of capital it has access to; (2) the frequency with which it is invited to co-invest in other VCs' deals, thereby expanding its investment opportunity set; (3) its ability to generate such co-investment opportunities in the future by syndicating its own (being lead investor) deals in the hope of future payback from its syndication partners.

\section{Network Count $=$ Total number firms a VC firm has co - invested with}

Additionally, following these researchers work on VC networks, two other measures were collected: (1) the number of times a VC firm has been lead investor and (2) the number of co-investment rounds. As both Hochberg et al. (2007) and Lerner (1994) discuss, these measures are also important in understanding the nature and size of a VC firm's network. Given their importance in understanding actual size and benefit of a firm's network, all three were combined to create a single construct $V C$ firm network. The combination of these network measures is in line with prior research on VC networks to capture the totality and importance of the firm's network (Ceston, 2006; Hopp and Lukas, 2014). To create the new construct, exploratory factor analysis (EFA) was used to identify the validity of the measure. Principal component analysis with a Varimax rotation yielded a single network factor. Cronbach's alpha coefficient for the construct exceeded the $0.80(0.83)$ lower bound for reliability measures in applied research (>0.7) (Nunnally, 1978).

Organizational performance. VC firms structure their funds as closed-end, often 10-year, and limited partnerships. They are not usually traded nor do they disclose fund valuations. The typical VC that has created a fund, spends its first three or so years selecting companies to invest in and then nurtures them over the next few years (Ljungqvist et al., 2005). In the second half of the fund's life, successful portfolio companies are exited via initial public offerings (IPOs) or sales to other companies, generating capital inflows that are distributed to the fund's investors. At the end of the fund's life, any remaining portfolio holdings are sold or liquidated and the proceeds distributed to investors.

As the ThomsonOne PE database lacks data on those capital inflows from positive exits, we adopted the exit rates; defined as the fraction of portfolio companies that are successfully exited via an IPO or a sale to another company in the VC's portfolio, as the primary performance measure for this investigation. Within the $\mathrm{VC}$ research and more specifically those using the ThomsonOne PE database, this is considered an acceptable measure of VC firm performance (Brander et al., 2002; Das et al., 2011; Gompers and Lerner, 1999, 2000; Hochberg et al., 2007; Sorenson, 2007).

$$
\text { Firm Performance }=\frac{\text { Number of Exits or Acquisitions of Portfolios Companies }}{\text { Total Number of Portfolio Companies }}
$$

Control variables. Controlling for other known determinants of VC fund performance is necessary and has been found to help eliminate certain confounding variables that could influence the effect of the variables of interest (Kaplan and Schoar, 2005). Consequently, we controlled for industry, location, VC type and text length which is consistent with prior research on VC firms and content analysis.

Industry. Evidence from prior research indicates that different industry focus may have an influence on both VC firm strategy and performance (Kaplan and Schoar, 2005; Hochberg et al., 2007). Each VC firm received a code for their specific industry focus as defined by the Venture Economics Industry Codes (VEIC). VEIC are proprietary codes developed by Thomson Reuters. As a control variable, each industry received a bivariate code, i.e. classified into a specific VEIC industry or not. In cases where no classification was provided, the firm received a 0 coding. After data collection, initial analysis revealed that only 89 firms had 
NEJE

25,1

committed capital of $60 \%$ or more to a single industry. Given the small sample of firms having an industry focus and the consistent negative relationship in the regression analysis, all industries were combined to create a single bivariate industry variable (i.e. $1=$ has industry focus, $0=$ no industry focus).

Location. Location is controlled in $\mathrm{VC}$ research, as it may influence both performance and strategy (Gompers and Lerner, 2000; Lindsey, 2008; Hsu, 2006; Landstrom, 2007). As it is quite likely to occur in socially responsible VC as well, location was controlled by coding where the VC firm was located (i.e. US based or not).

$V C$ type. VC firms and funds can be set up as privately held entities, or connected to banks, corporations and governments, which may also have a social mission. As these corporate VC firms may vary from independent $\mathrm{VC}$ firms in terms of incentives and resources gained from connections with larger organizations (Zarutskie, 2010), this was also controlled.

Text length. The length of mission statements had a range of 400 words, indicating wide discrepancy in text length, hence following other content analytic studies it was controlled (i.e. Doucet and Jehn, 1997; Emrich et al., 2001; Short et al., 2010).

\section{Content analysis}

Key word list. Content analysis was used to identify the degree to which the firm's mission statement was related to social innovation. Weber's (1990) widely accepted process for content analysis was followed for the analysis of the mission statements (Morris, 1994; Duriau et al., 2007; Short et al., 2010; Moss et al., 2011). The measurement instrument for the construct socialness was adopted from Jones and Salimath (2015) which utilizes both deductive and inductive processes to ensure validity and reliability. For a firm to be considered social, it must adopt one of five different types of investment strategies (general, environment, social, governance or product/industry-related factors). This classification is consistent with both research (Randjelovic et al., 2003; Scholtens, 2006; Cumming and Johan, 2007; Jones and Salimath, 2015) and practice in the categorization of social responsible investing (Schueth, 2003; USSIF, 2012; GIIRS, 2014). For clarity, the general category refers to language that is not necessarily directly linked to the context of any of the other categories but to the overall premise of ESG value system. For example, this consisted of words or phrases such as accountability, corporate social responsibility, impact, etc. To evaluate the presence of language consistent with a socially related mission in the mission statements of the sample of VC firms, a one sample $t$-test was conducted for each dimension of social investing (Short et al., 2010). All dimensions were significant suggesting that language (consistent with a social investing orientation) was communicated in the firm mission statements across the sample.

To ensure content validity, a formal definition of the construct (i.e. social investing) was first synthesized from a review of extant literature and practical usage in the VC industry. In general, social/socially responsible investors (SRI) encourage corporate practices that promote environmental stewardship, consumer protection, human rights and diversity. The areas recognized by the SRI industry may be summarized as environmental, social (justice) and governance (ESG) issues. SRI can narrowly refer to practices seeking to avoid harm by screening companies included in an investment portfolio or broadly refer to more proactive practices (i.e. impact investing, shareholder advocacy, community investing). Based on this definition, a classification scheme was identified such that if a firm is to be considered social it must adopt one of four different types of investment strategies (environment, social, governance or product/industry-related factors).

Starting with a deductive process, discrete key words lists were drawn from existing research and Rodale's (1978) The Synonym Finder for each of the four dimensions. Following prior scholars (Doucet and Jehn, 1997), an inductive process helped identify words that may not have been captured through a deductive process. Finally, a panel of three experts 
Social investing dimensions Content analysis words with expert validation

General

Environment

Social

Governance

Product \& industry stock screening, stewardship, philanthropy product take-back programs, cap and trade diversity, community development
Accountability, corporate social responsibility, ethics, impact, mission, values,

Air pollution, air quality, alternative energy, biomass, carbon emission, clean energy, clean tech, climate, climate change, conservation, emissions, energy efficiency, energy star, energy storage, environment, environmental, environmental impact, environmental performance, environmental stewardship, green, green building, hazardous waste, hybrid, hydro-power, land conservation, LEED (leadership in energy and environmental design), LOHAS (lifestyle of health and sustainability), natural resources, organic, pollution, recycling, renewable, renewable energy, resource conservation, smart growth, solar, sustainability, sustainable agriculture, sustainable consumption, sustainable forestry, toxin, waste reduction, water, water desalination, water efficiency, water purification, water reuse, wind, solar energy, environmental management systems (EMS), wind energy, wildlife conservation, hybrid energy, ISO 14001 certification, green engineering,

Affordable housing, charitable giving, civic engagement, community, conflict minerals, disabled, disadvantaged, diversity, economic development, economic impact, employee involvement, employee relations, empowerment, equal opportunity, ethnicity, gay, lesbian, ethnicity, gender, human rights, job creation, labor issues, labor rights, life benefits, local development, low-income, microcredit, minorities, oppressive regimes, poverty, profit sharing, race, safety, social, social benefits, social enterprise, social entrepreneurship, social impact, social performance, social responsibility, transparency, underserved, union relations, urban planning, volunteer, corporate philanthropy, racial diversity, sustainable development, community relations, ethnic diversity, gender diversity, religious

Anti-corruption, board compensation, board composition, executive compensation, shareholders, stakeholders, stakeholder involvement, top management compensation, information transparency, auditors, legal compliance, strategic direction, oversight, shareholder proposals, disclosure, governance Affordable health care, alcohol, ammunition, defense, ethical medicine, firearms, gambling, healthcare, medicine, military, nuclear power, pharmaceuticals, pornography, tobacco, weapons
Architectural dimensions of social VC firms
Table 1. Word list for social investing dimensions

determined the reliability of these key words list. The experts helped to identify words that did not sufficiently relate to the construct and included additional new words to the initial list. The expert panel consisted of two academic scholars and a practitioner in social investing realm. Through this deductive and inductive process, 171 initial words were identified, including 29 additional words identified by the raters.

To evaluate the presence of language consistent with a socially related mission, a one sample $t$-test (compared to a test statistic of zero) was conducted for each dimension of social investing (Short et al., 2010). All dimensions were significant suggesting that language (consistent with a social investing orientation) was communicated in the firm mission statements across the sample.

To enhance reliability, computer-aided text analysis (CATA) was used to minimize error from human coders. CATA generally assesses content via word usage (Morris, 1994). It assumes that insights about the authors' mental models can be revealed by the presence/ absence of and frequency with which certain concepts are used in text (Carley, 1997).

The DICTION 6.0 (Hart, 2000) software was used for content analysis and has been used in other entrepreneurship contexts (Short et al., 2010; Moss et al., 2011; McKenny et al., 2012). DICTION was developed to analyze political speech and rhetoric (Hart and Jarvis, 1997) and 
NEJE

25,1

focuses on the power of word choice and verbal tone (Hart, 1984). DICTION also utilizes elements of artificial intelligence. The software has self-learning capacity to remember user decisions and can accommodate confounding homographs.

A coding scheme was developed for the review, by the panel of experts, of each word list based on a scale from 1 (not related) to 100 (completely related). This scale was then converted to a nominal scale, whereby scores over 50 were related and the rest were unrelated. Holsti's (1969) Proportion of Agreement Observed (PAO) was used to demonstrate interrater reliability (IRR). For the three raters, the PAO was calculated by the following equation:

$$
\text { Proportion of Agreement Observed }(\mathrm{PAO})=3 * \mathrm{~A} /(\mathrm{nA}+\mathrm{nB}+\mathrm{nC})
$$

where $\mathrm{A}=$ number of agreed upon words by all raters and $\mathrm{nA}, \mathrm{nB}$ and $\mathrm{nC}=$ number of sufficiently related words per rater. IRR coefficients for all five dimensions were above the generally accepted rule of thumb i.e. the 0.70 heuristic for coefficient a (Ellis, 1994; Krippendorff, 2004; Riffe et al., 2019). The final word list consisted of 148 words. A complete listing of the key words in each category is provided in Table 1.

\section{Analysis and results \\ Analysis}

To examine the complexities of the moderated mediation model, an alternative and well used statistical approach (Preacher and Hayes, 2008) was used to test all the hypothesized relationships due to its capacity to simultaneously handle complex evaluations.

Results

Results of the bivariate (Pearson) correlations were somewhat mixed for the relationships between the multiple dimensions of social mission and the primary dependent variable, $\mathrm{VC}$ firm performance (exits) (Table 2). While five of the six dimensions of social mission were significantly related to firm performance, only the social and governance dimensions were positive. The results of the bivariate correlations provide some initial insight into the relationships of interest.

\section{Hypotheses testing}

Hypothesis 1 addressed the positive relationship between the social mission and firm performance (positive portfolio firm exits). Hierarchical regression analysis results are presented in Table 3. As depicted in Model 2, while the overall model was significant $\left(F=11.753, R^{2}=0.228, p<0.001\right)$, only governance $(\beta=0.092, p<0.05)$ and product/industry $(\beta=0.125, p<0.05)$ was significant and positively related to $\mathrm{VC}$ firm performance (exits). Thus, Hypothesis 1 was partially supported.

Hypothesis 2 proposed a direct and positive relationship between social mission and investing in early stage portfolio companies by the $\mathrm{VC}$ firm. Multiple regression analysis results are presented in Table 3. As seen under the Early Stage model, four of the five dimensions (general, environmental, governance, product/industry) of social mission were significant but negatively related to early stage investments. Thus, Hypothesis 2 was unsupported. This provides some initial indication that even socially responsible VC firms may be diversifying their investments across different stages and may not rely solely on seed/ early stage investment opportunities.

To test the mediating relationships in H3, MacKinnon's (2000) multiple mediation model was used and three separate regression equations were estimated. A single regression was entered simultaneously for each dimension variable to correct for any multicollinearity. Results of this analysis (Table 3, Model $4, R^{2}=0.296, F=15.04, p<0.001$ ) indicate that governance was $91 \%$ mediated (Table 3 , Model $4, \beta=0.044, n . s$.) as the coefficient became nonsignificant. Additionally, product/industry was only $23 \%$ mediated (Table 3 , Model 4, 


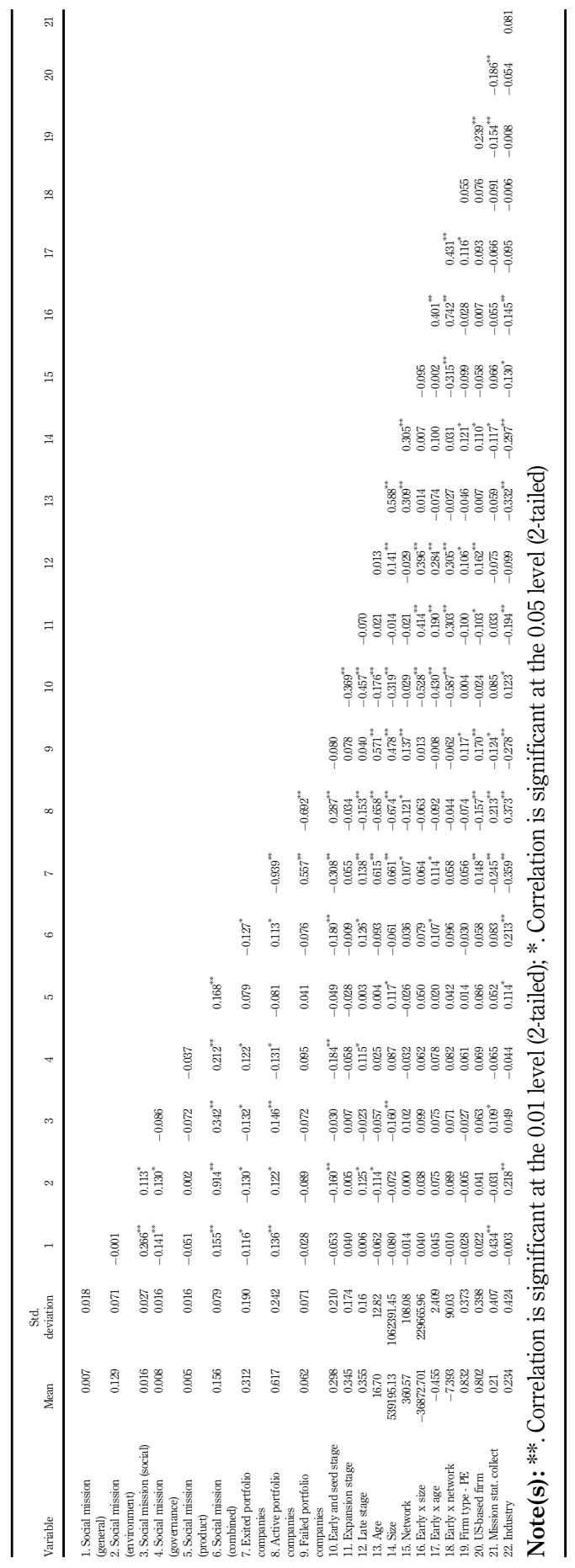

Architectural dimensions of social VC firms

Table 2. Means, standard deviations and correlations 
NEJE

25,1

38

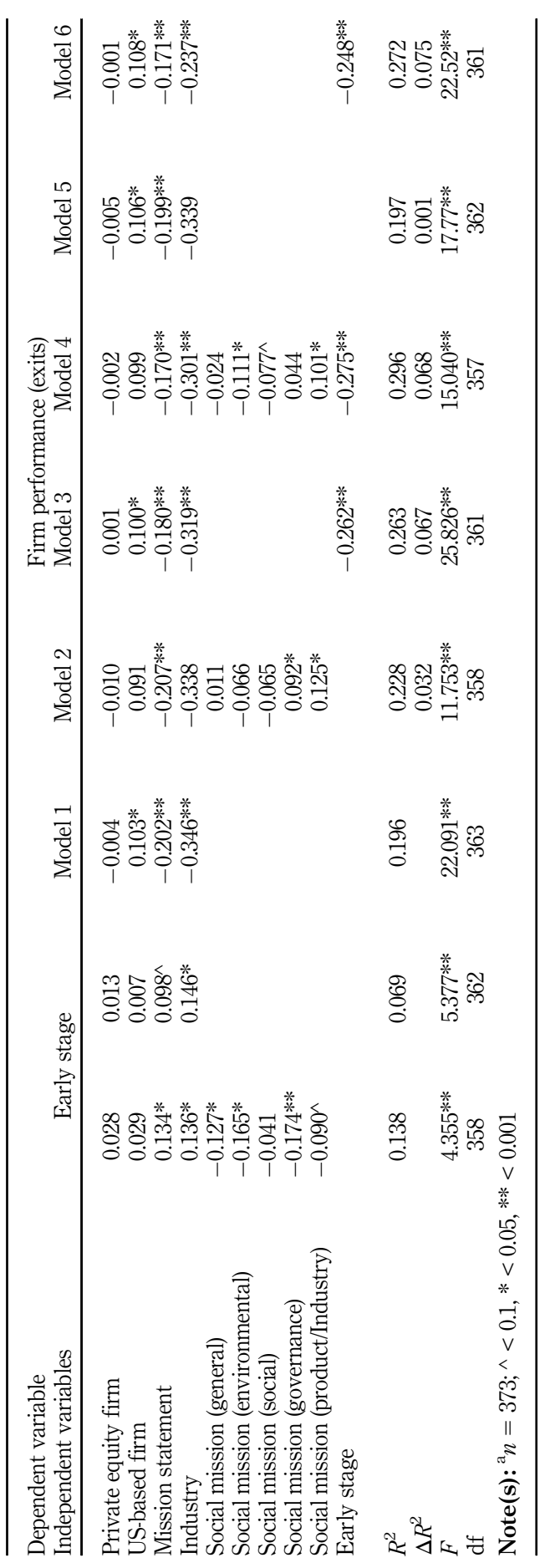

Table 3.

Results of the

standardized

regression analysis for the mediated effects ${ }^{\mathrm{a}}$ 
$\beta=0.101, p<0.05$ ) indicating partial mediation; providing partial support for $\mathrm{H} 3$. It should be noted that there was inconsistent mediation for both these mediated relationships, as the direct effects were positive, but negative from early stage to $\mathrm{VC}$ performance. In addition, inclusion of early stage investments into the model resulted in the environmental and social dimensions becoming significant. Sobel's test (Preacher and Leonardelli, 2001) for the mediation of the governance - VC firm performance relationship was significant (Sobel $Z$-test $=5.72^{* *}$ ) and $91 \%$ of the total effect was mediated. For the product/industry - VC firm performance, Sobel's test was not significant. Therefore, results provided only partial support dimensions of social VC firms for Hypothesis 3.

Hierarchical regression was conducted to test the moderating Hypotheses $4 \mathrm{a}$ and $4 \mathrm{~b}$. Means were compared to test the curvilinear relationship proposed in H4a of the four size quartiles in relation to $\mathrm{VC}$ firm performance and did not follow curvilinear pattern as they only increased with each quartile. Furthermore, results, as indicated in Model 4 in Table 4 $\left(R^{2}=0.507, \Delta R^{2}=0.311, F=52.8, p<0.001\right)$, revealed that the quadratic term size $e^{2}$ was not significant. When the interaction term for the quadratic term size $e^{2}$ was entered in the model, there was no change in variance explained and the quadratic term $s i z e^{2}$ and the interaction term were nonsignificant. Thus, H4a was not supported. This is interesting as it indicates that as early stage investments increased, performance decreased for the three groups of larger firms. Alternatively, for the smallest sized firms, as early stage investments increased, performance also increased.

Further analysis was conducted to determine whether size moderated the relationship linearly. As indicated in Model 2 in Table 4, when size was entered in the model, the variance explained was $50 \%\left(R^{2}=0.506, \Delta R^{2}=0.31, F=61.66, p<0.001\right)$ and size $(\beta=0.549$, $p<0.001$ ) was positive and significantly related to $\mathrm{VC}$ firm performance. The interaction term (Model 3) only marginally increases the variance explained $\left(R^{2}=0.514, \Delta R^{2}=0.008\right.$, $F=54.37, p<0.001)$ and the interaction term was negative and significant $(\beta=-0.132$, $p<0.05)$, indicating that size negatively moderates the early stage investments-VC firm

\begin{tabular}{|c|c|c|c|c|c|c|c|}
\hline \multirow{2}{*}{$\begin{array}{l}\text { Dependent } \\
\text { variable } \\
\text { Independent } \\
\text { variables } \\
\end{array}$} & \multicolumn{5}{|c|}{ VC firm performance exit } & \multirow[b]{2}{*}{ Model 6} & \multirow[b]{2}{*}{ Model 7} \\
\hline & Model 1 & Model 2 & Model 3 & Model 4 & Model 5 & & \\
\hline $\begin{array}{l}\text { Private equity } \\
\text { firm }\end{array}$ & -0.004 & -0.054 & -0.051 & -0.054 & -0.054 & -0.004 & 0.000 \\
\hline US-based firm & $0.103^{*}$ & $0.067^{\wedge}$ & $0.071^{\wedge}$ & $0.068^{\wedge}$ & $0.067^{\wedge}$ & $0.108^{*}$ & $0.112^{*}$ \\
\hline $\begin{array}{l}\text { Mission } \\
\text { statement }\end{array}$ & $-0.202^{* *}$ & $-0.146^{* *}$ & $-0.138^{* *}$ & $-0.147^{* * *}$ & $-0.146^{* *}$ & $-0.188^{* *}$ & $-0.188^{* *}$ \\
\hline Industry & $-0.346^{* *}$ & $-0.176^{* *}$ & $-0.186^{* *}$ & $-0.177 *$ & $-0.175^{* *}$ & $-0.323^{* *}$ & $-0.319 * *$ \\
\hline $\begin{array}{l}\text { Early stage } \\
\text { investment }\end{array}$ & & $-0.111^{*}$ & -0.020 & $-0.110^{*}$ & $-0.117^{*}$ & $-0.235^{* *}$ & $-0.314^{* *}$ \\
\hline $\begin{array}{l}\text { Size } \\
\text { Size }^{2}\end{array}$ & & $0.549 * *$ & $0.529 * *$ & $\begin{array}{l}0.545^{* *} \\
0.022\end{array}$ & $\begin{array}{l}0.545^{* *} \\
0.056\end{array}$ & & \\
\hline Network & & & & & & $0.074^{\wedge}$ & 0.030 \\
\hline $\begin{array}{l}\text { Early } \times \text { size } \\
\text { Early } \times \text { size }^{2}\end{array}$ & & & $-0.132^{*}$ & & $\begin{array}{c}-0.135^{*} \\
0.040\end{array}$ & & \\
\hline Early $\times$ network & & & & & & & $-0.133^{*}$ \\
\hline$R^{2}$ & 0.196 & 0.506 & 0.514 & 0.507 & 0.507 & 0.268 & 0.277 \\
\hline$\Delta R^{2}$ & & 0.310 & 0.008 & 0.311 & 0.000 & 0.06 & 0.010 \\
\hline$F$ & $22.09 * *$ & $61.66 * *$ & $54.37 * *$ & $52.8^{* *}$ & $46.132^{* *}$ & $21.25^{* *}$ & $19.08^{* *}$ \\
\hline $\mathrm{df}$ & 363 & 361 & 360 & 363 & 360 & 349 & 348 \\
\hline
\end{tabular}

Table 4. Results of the standardized regression analysis for the moderation effects ${ }^{\mathrm{a}}$

Note(s): ${ }^{\mathrm{a}} n=367,{ }^{2}$ Quadratic variable, ${ }^{\wedge} p<0.1,{ }^{*} p<0.05,{ }^{* *} p<0.001$ 
NEJE

25,1

40

performance relationship. Figure 2 is presented to aid in the interpretation of this interaction effect. Based on the graphical depiction, the three largest quartiles of size (the largest firms) have the same effect, i.e. as the amount of early stage investments increase, VC firm performance decreases.

Hypothesis $4 \mathrm{~b}$ tested the moderating relationship of firm network (see Table 4). Network was marginally significant $(\beta=0.074, p<0.1)$ in relation to VC firm performance when entered in Model $6\left(R^{2}=0.269, \Delta R^{2}=0.06, F=21.25, p<0.001\right)$. In Model 7, the interaction term was included and was negative and significantly $(\beta=-0.133, p<0.05)$ related to $\mathrm{VC}$ firm performance. Thus, Hypothesis $4 \mathrm{~b}$ was not supported as there was a negatively moderated relationship. Figure 3 graphically represents this effect. The disordinal interaction effect indicates that as investment in early stage investment increases, performance decreased for all firm network sizes.

Analysis of the full model was conducted using the Preacher and Hayes (2008) technique for moderated mediation using the two dimensions of social mission (governance and product) industry) that were significantly mediated by early stage investment. Interestingly, the product/industry dimension was negative but not significantly $(\beta=-0.564, n . s$. $)$ related to early stage investment. This does not fulfill the requirements for mediation and contrasts with results of the analysis conducted for Hypothesis 2, providing no support for the moderated mediation model with the product/industry dimension.

Results of the moderated mediation model presented indicated governance became nonsignificant $(\beta=-0.587, n . s$.) and that only the early stage-size interaction term was marginally significant $(\beta=-0.075, p<0.1)$. These results provide additional support for an overall moderated mediation model. As recommended by Preacher et al. (2007), bootstrapped confidence intervals were generated (5,000 resamples) for the conditional indirect effects. Three combinations of moderator levels yielded a bootstrap 95\% bias corrected and accelerated confidence intervals when size and network were at the mean, when size was one

Figure 2.

The moderating effect of size on the association between early stage investment and $\mathrm{VC}$ performance $(\text { Exits) })^{\mathrm{a}}$

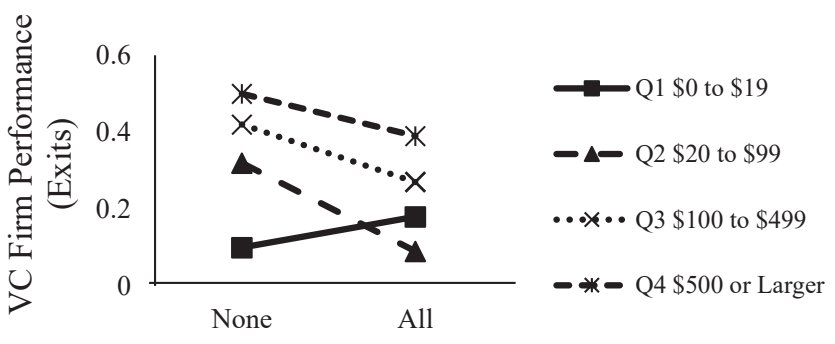

Amount of Early Stage Invesments

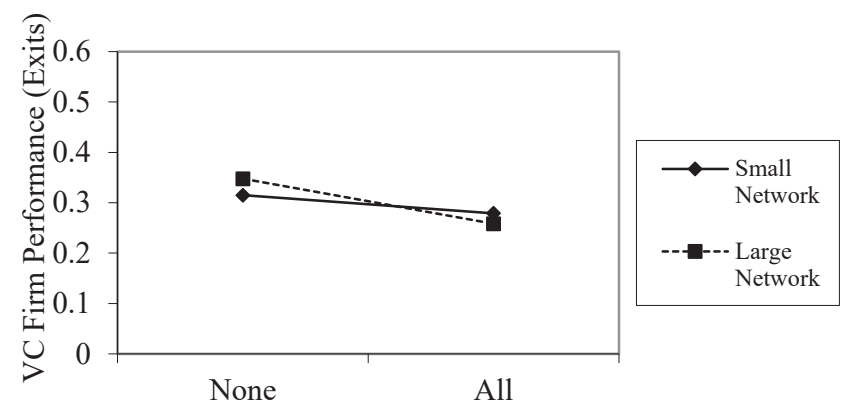

Amount of Early Stage Investment
Figure 3.

The moderating effect of network on the association between early stage investment and VC firm performance (exits) 
s.d. above and network was at the mean, and when both size and network were one $s . d$. above the mean. Results indicate, based on the additional indirect effect explained, as size and network increase, overall effect increases. No total/mediated effect is presented as the concern was only with conditional indirect effect (Hayes, 2009).

\section{Discussion}

The central argument was that strategic orientation (mission) would influence firm architecture (via strategy and structure) and affect performance. Results however offered limited and partial support to the proposed moderated mediation model, indicating that there is scope for probing these effects further. The lack of support (two hypotheses were not supported, and two had limited support) may be due to two factors: (1) broad terminology of key word lists and (2) life span of VC investments and VC funds. A reexamination of the key word lists for each dimension revealed that they could be broadly grouped together. The first group (environmental and social dimensions) relates to very specific niche markets and/or orientations (e.g. words like environmental, clean-tech, air pollution, energy storage, hybrid, water purification, etc.) and may not generalize to a large population of VC firms. Alternatively, the second grouping of dimensions (governance and product/industry) include more general terms that could even be included in the mission statements of VC firms that may not have a social orientation, i.e. compensation, shareholders, stakeholders, top management, disclosure, strategic direction and healthcare. It is likely that these more general terms might be included in mission statements of a broad range of $\mathrm{VC}$ types not just the socially oriented.

A second factor, life span of VC investments and VC funds, combined with the first (broad terminology) offers a promising explanation for the obtained results. The life span of VC investments is typically between 3 and 5 years, and around 10 years for VC funds. Given this life cycle, prior VC research generally used a 5-10 year period prior to the date of the investigation to allow a portfolio company to go through the entire life cycle process (Hochberg et al., 2007; Lindsey, 2008; Dimov and Milanov, 2010). Additionally, VC funds make most of their investments within first three years of the funds start, so without this interval there may not be enough time for a portfolio company to exit the investment. Given that the passage of time is necessary for investments to mature and come to exit, future examination is warranted. Based on this life cycle issue and the relative newness of socially responsible $\mathrm{VCs}$, it is reasonable that more socially oriented firms may not have gone through the full life cycle process and thereby not had the exits seen in older/established firms.

An additional important finding is that socially innovative $\mathrm{VC}$ firms follow similar review and investment processes as other VC firms (Reandjelovic et al., 2003). The results, however, indicate that as a VC firm's social orientation increases, they opt to diversify to reduce unsystematic risk. Additionally, diversification strategies in investment stage are driven by potential opportunities for investments themselves.

While curvilinear relationships of size were unsupported statistically, the conceptually take-a-way is that there is a point at which firm performance for early stage investments declines as firm size grows. Prior research supports the notion that while size is important for performance, the relationship is concave (Hochberg et al., 2007). Plausible explanations suggest that larger firms maintain diversified portfolios which include very high-risk early stage investments that provide minimal rewards (MacMillan et al., 1986).

The negative and significant relationship of the network moderator appears to be statistically produced because of the negative relationship that early stage investments had with performance, as networks had a significant and positive direct effect on VC firm performance. Even considering this finding, it is still likely that syndication is a good strategy for VC firms and working to grow that network may lead to new/better investment opportunities and performance (Gorman and Sahlman, 1989; Dimov and Milanov, 2010). 
NEJE

25,1

When VC firms choose to engage in social innovation, the process appears to be similar to firms seeking financial success. Thus, they need a clearly articulated starting objective and end goal (such as social, environmental and economic performance). The actual implementation of social innovation objectives can occur through appropriate firm structures and strategies. Social innovation needs requisite architecture at the firm level through which it can be channeled and realized.

Finally, there is growing recognition that sustainability in the financial service (VCs included) comes in the form of governance, accountability and broadening the stakeholder view. In the financial services sector, fringe corporate social responsibility programs (e.g. recycling programs, energy efficient lighting, etc.) result in neither sustainability nor societal impact (Eccels and Serafeim, 2013). Rather, it contributes to the disclosure, accountability and responsibility toward products and services these institutions provide (i.e. governance) (Catto, Arthur, Keenoy, and Smith, 2008). If more generalized VC firms are adopting a governance-based form of social investing, a major secondary outcome is that research on social investing should become more precise in intent, i.e. focus on firms actually investing in socially innovative ideas/individuals or focus on firms investing in all types of ventures but also believe governance and stakeholders are important. This provides further support to examining the ESG categories of social investing as a multidimensional construct, with each dimension having different meanings, strategies, and outcomes.

\section{Contributions and limitations}

The primary take-a-way is that firms can select distinct dimensions to focus their social orientations, with differential effects on firm overall performance, the strategic decisions made and their structural designs. It is therefore necessary to treat each dimension separately in examining the outcomes of social innovation in VC firms. Different social foci should again be treated separately given differences in strategies, industry and investment focus and market orientations.

Some investment strategies are more advantageous (financially speaking) depending of the size of the firm and the socialness of the firm's orientation. Specifically, investing in early stage investments is a better and even more meaningful investment for small and more socially oriented firms. This suggests that while embedded institutional norms (i.e. profit orientation in the capital markets) resist challenge/change, $\mathrm{VC}$ firms are responding to these pressures by smart investments in socially innovative ways, thereby indirectly changing existing logics. It is becoming acceptable to do good as you continue to do well.

Despite potential contributions, we note limitations to the study. The database has an oversampling of US-based VC firms, affecting generalizability. As discussed earlier, the use of computerized content analysis may cause nonhuman errors in interpretation. The inclusion of for-profit firms only limits the sample range. Furthermore, firm's sometimes using mission statements as deliberate signaling mechanisms that may not reflect strategic intent. Hence, results should be understood within these caveats and limitations. Including other relevant factors besides investment stage might increase predictive power. Allowing time for VCs to experience life cycle till exit stage could be considered. Therefore, results for social performance are more likely when VC firms implement their stated social mission through appropriate firm structure and strategy.

Additionally, it should be noted that the original focus for analysis was intended to be at the fund level as VC firms comprise of various funds with different objects. As a majority of individual funds lacked their own explicit mission, firm-level data for all variables were collected. It is understood that a VC firm may have several funds (with diverse orientations), but given the data constraint, the focus of the study remained at the firm level. Future research can focus at the fund level specifically. 
This study advances knowledge on socially responsible VCs without a lengthy history of scholarly output. This empirical investigation is among the first to explore socially responsible VC architectural dimensions, with implications for firms designing their organization based on blended measures of success. We call upon future scholars on socially responsible VCs to (1) investigate longitudinal effects of different types of social orientation on firm performance, (2) compare socially oriented firms vs others and (3) examine the sample after all VC firms had the opportunity to go through at least one entire VC life cycle process.

\section{References}

Abell, P. and Nisar, T.M. (2007), "Performance effects of venture capital firm networks", Management Decision, Vol. 45 No. 5, pp. 923-936.

Adams, D. and Hess, M. (2011), "Social innovation and why it has policy significance", Economic and Labour Relations Review, Vol. 21 No. 2, p. 139.

Alsmadi, S. (2007), "Green marketing and the concern over the environment: measuring environmental consciousness of Jordanian consumers", Journal of Promotion Management, Vol. 13 Nos 3-4, pp. 339-361.

Argarwal, D., Bersin, J. and Lahiri, G. (2018), The Rise of the Social Enterprise, Human Capital Trend Report, Deloitte Development LLC, p. 60.

Averitt, R.T. (1968), The Dual Economy: the Dynamics of American Industry Structure, W.Norton, New York.

Bart, K. and Baetz, M. (1998), "The relationship between mission statements and firm performance: an exploratory study", Journal of Management Studies, Vol. 35 No. 6, pp. 823-853.

Bhatt, P. and Altinay, L. (2013), "How social capital is leveraged in social innovations under resource constraints?", Management Decision, Vol. 51 No. 9, pp. 1772-1792.

Brander, J., Amit, R. and Antweiler, W. (2002), "Venture capital syndication: improved venture selection versus the value-added hypothesis", Journal of Economics and Management Strategy Vol. 11, pp. 423-452.

Bright, D. and Godwin, L. (2010), "Encouraging social innovation in global organizations: integrating planned and emergent approaches", Journal of Asia - Pacific Business, Vol. 11 No. 3, p. 179.

Bull, M. (2008), "Challenging tensions: critical, theoretical and empirical perspectives on social enterprise", International Journal of Entrepreneurial Behavior and Research, Vol. 14 No. 5, pp. 268-275.

Capelle-Blancard, G. and Monjon, S. (2014), "The performance of socially responsible funds: does the screening process matter?”, European Financial Management, Vol. 20 No. 3, pp. 494-520.

Carley, K.M. (1997), "Extracting team mental models through textual analysis", Journal of Organizational Behavior, Vol. 18, pp. 533-558.

Carroll, A. (1991), "The pyramid of corporate social responsibility: toward the moral management of organizational stakeholders", Business Horizons, Vol. 34 No. 4, pp. 39-48.

Cato, M.S., Arthur, L., Keenoy, T. and Smith, R. (2008), "Entrepreneurial energy: associative entrepreneurship in the renewable energy sector in Wales", International Journal of Entrepreneurial Behavior and Research, Vol. 14 No. 5, pp. 313-329.

Cestone, G. (2006), The Design of Syndicates in Venture Capital, Fundacion BBVA, Unpublished working paper.

Chandler, A. (1969), Strategy and Structure: Chapters in the History of the American Industrial Enterprise, MIT Press, Boston, Massachusetts, MA.

Cumming, D. and Johan, S. (2007), "Socially responsible institutional investment in private equity", Journal of Business Ethics, Vol. 75 No. 4, pp. 395-416.

Das, S., Jo, H. and Kim, Y. (2011), "Polishing diamonds in the rough: the sources of syndicated venture performance", Journal of Financial Intermediation, Vol. 20, pp. 199-230. 
NEJE

25,1

Dimov, D. and Milanov, H. (2010), "The interplay of need and opportunity in venture capital investment syndication”, Journal of Business Venturing, Vol. 25 No. 4, pp. 331-348.

Dimov, D., Shepherd, D.A. and Sutcliffe, K.M. (2007), "Requisite expertise, firm reputation, and status in venture capital investment allocation decisions", Journal of Business Venturing, Vol. 22 No. 4, pp. 481-502.

Doucet, L. and Jehn, K.A. (1997), "Analyzing harsh words in a sensitive setting: American expatriates in communist China”, Journal of Organizational Behavior, Vol. 18 No. S1, pp. 559-582.

Duriau, V.J., Reger, R.K. and Pfarrer, M.D. (2007), "A content analysis of the content analysis literature in organization studies: research themes, data sources, and methodological refinements", Organizational Research Methods, Vol. 10 No. 1, pp. 5-34.

Eccles, R. and Serafeim, G. (2013), “The performance Frontier: innovating for a sustainable strategy”, Harvard Business Review May, pp. 1-10.

Ellis, N.C. (1994), "Implicit and explicit language learning", Implicit and Explicit Learning of Languages, pp. 79-114.

Emrich, C.G., Brower, H.H., Feldman, J.M. and Garland, H. (2001), "Images in words: presidential rhetoric, charisma, and greatness", Administrative Science Quarterly, Vol. 46 No. 3, pp. 527-557.

Ginsberg, A. and Venkatraman, N. (1985), "Contingency perspectives on organizational strategy: a critical review of the empirical research", Academy of Management Review, Vol. 5, pp. 25-39.

Global Impact Investing Rating System (2014), "What is impact investing”, available at: http://www. giirs.org/about-giirs/about (accessed 12 December 2014).

Gompers, P.A. and Lerner, J. (1999), "What drives venture capital fundraising?", Brookings Papers on Economic Activity: Microeconomics, Vol. 1998, pp. 149-204.

Gompers, P.A. and Lerner, J. (2000), "Money chasing deals? The impact of fund inflows on private equity valuations", Journal of Financial Economics, Vol. 55, pp. 281-325.

Gorman, M. and Sahlman, W.A. (1989), "What do venture capitalists do?", Journal of Business Venturing, Vol. 4 No. 4, pp. 231-248.

Goyal, S., Sergi, B.S. and Jaiswal, M.P. (2016), "Understanding the challenges and strategic actions of social entrepreneurship at base of the pyramid”, Management Decision, Vol. 54 No. 2, pp. 418-440.

Gulati, R. (1998), “Alliances and networks”, Strategic Management Journal, Vol. 19 No. 4, pp. 293-317.

Guyatt, D.J. (2006), "Identifying and overcoming behavioural impediments to long term responsible investment: a focus on UK institutional investors", available at: https://ssrn.com/ abstract $=1911821$.

Hair, J.F. (2009), Multivariate Data Analysis: A Global Perspective, 7th ed., Prentice Hall, Upper Saddle River.

Hamilton, S., Jo, H. and Statman, M. (1993), "Doing well while doing good? The investment performance of socially responsible mutual funds", Financial Analysts Journal, Vol. 49 No. 6, pp. 62-66.

Harrigan, K.R. (1983), "Research methodologies for contingency approaches to business strategy", Academy of Management Review, Vol. 8, pp. 398-405.

Hart, R.P. (1984), Verbal Style and the Presidency: A Computer-Based Analysis, Academic, New York, NY.

Hart, R.P. (2000), DICTION 5.0: the Text-Analysis Program, Scolari/Sage, Thousand Oaks, California, CA.

Hart, R.P. and Jarvis, S.E. (1997), "Political debate: forms, styles and media", American Behavioral Sciences, Vol. 40, pp. 185-122.

Hayes, A.F. (2009), "Beyond Baron and Kenny: statistical mediation analysis in the new millennium", Communication Monographs, Vol. 76 No. 4, pp. 408-420.

Hochberg, Y.V., Ljungqvist, A. and Lu, Y. (2007), "Whom you know matters: venture capital networks and investment performance", The Journal of Finance, Vol. 62 No. 1, pp. 251-301. 
Hoepner, A.G. and McMillan, D.G. (2009), "Research on responsible investment: an influential literature analysis comprising a rating, characterization, categorization and investigation", available at: SSRN:https://ssrn.com/abstract $=1454793$.

Holsti, O.R. (1969), Content Analysis for the Social Sciences and Humanities, Addison-Wesley, Reading, Massachusetts, MA.

Hopp, C. and Lukas, C. (2014), "A signaling perspective on partner selection in venture capital syndicates", Entrepreneurship Theory and Practice, Vol. 38 No. 3, pp. 635-670.

Hsu, D.H. (2006), "Venture capitalists and cooperative start-up commercialization strategy", Architectural dimensions of social VC firms Management Science, Vol. 52 No. 2, pp. 204-219.

Ingenhoff, D. and Fuhrer, T. (2010), "Positioning and differentiation by using brand personality attributes: do mission and vision statements contribute to building a unique corporate identity?", Corporate Communications: An International Journal, Vol. 15 No. 1, pp. 83-101.

Jones, R. (2013), Social Innovation in Venture Capital Firms: Strategy, Structure, and Performance, [Doctoral dissertation, University of North Texas], UNT Campus Repository, available at: https://digital.library.unt.edu/ark:/67531/metadc407767/m2/1/high_res_d/dissertation.pdf?.

Jones, R. and Salimath, M. (2015), “Toward an objective measurement tool: measuring firm socialness using computer-aided text analysis (CATA)", 2015 USASBE Annual Conference Proceedings.

Kaplan, R.S. and Norton, D.P. (2001), "Transforming the balanced scorecard from performance measurement to strategic management: Part I", Accounting Horizons, Vol. 15 No. 1, pp. 87-104.

Kaplan, S.N. and Schoar, A. (2005), "Private equity returns: persistence and capital flows", Journal of Finance, Vol. 60, pp. 1791-1823.

Kaplan, S., Sensoy, B. and Stromberg, P.(2002), How Well Do Venture Capital Databases Reflect Actual Investments?, Working Paper, University of Chicago, SSRN 939073, available at: http://citeseerx. ist.psu.edu/viewdoc/download?doi=10.1.1.128.4532\&rep=rep1\&type=pdf.

Kelly, D. and Amburgey, T.L. (1991), "Organizational inertia and momentum: a dynamic model of strategic change", Academy of Management Journal, Vol. 34 No. 3, pp. 591-612.

Kempf, A. and Osthoff, P. (2007), "The effect of socially responsible investing on portfolio performance", European Financial Management, Vol. 13 No. 5, pp. 908-922.

Krippendorff, K. (2004), "Reliability in content analysis", Human Communication Research, Vol. 30 No. 3, pp. 411-433.

Kurtz, L. (1997), "No effect, or no net effect? Studies on socially responsible investing", The Journal of Investing, Vol. 6 No. 4, pp. 37-49.

Landstrom, H. (2007), Handbook of Research on Venture Capital, Edward Elgar Publishing, Northampton, Massachusetts, MA.

Lerner, J. (1994), “The syndication of venture capital investments", Financial Management, Vol. 23 No. 3, pp. 16-27.

Lerner, J. (2009), Boulevard of Broken Dreams: Why Public Efforts to Boost Entrepreneurship and Venture Capital Have Failed - and what to Do about it, Princeton University Press, Princeton.

Lindsey, L. (2008), "Blurring firm boundaries: the role of venture capital in strategic alliances", The Journal of Finance, Vol. 63 No. 3, pp. 1137-1168.

Ljungqvist, A., Richardson, M. and Wolfenzon, D. (2005), The Investment Behavior of Private Equity Fund Managers, Working Paper, New York University, available at: https://archive.nyu.edu/ bitstream/2451/26660/2/S-AM-03-12.pdf.

MacKinnon, D.A. (2000), "Contrasts in multiple mediator models", in Rose, J.S., Chassin, L., Presson, C.C. and Sherman, S.J. (Eds), Multivariate Applications in Substance Use Research: New Methods for New Questions, Erblaum, Mahwah, New Jerssey, NJ, pp. 141-160.

MacMillan, I.C., Siegel, R. and Narasimha, P.N. (1986), "Criteria used by venture capitalists to evaluate new venture proposals", Journal of Business Venturing, Vol. 1 No. 1, pp. 119-128. 
NEJE

25,1

McKenny, A.F., Short, J.C. and Payne, G.T. (2012), "Using computer-aided text analysis to elevate constructs: an illustration using psychological capital", Organizational Research Methods, Vol. 16 No. 1, pp. 152-184.

Meles, A. (2021), "Venture capital and responsible investing: progress, problems and perspectives", The Evolution of Sustainable Investments and Finance: Theoretical Perspectives and New Challenges, Palgrave Macmillan, pp. 211-250.

Miller, D. (1986), "Configurations of strategy and structure: towards a synthesis", Strategic Management Journal, Vol. 7 No. 3, pp. 233-250.

Miller, T.L., Wesley, I.I. and Curtis, L. (2010), "Assessing mission and resources for social change: an organizational identity perspective on social venture capitalists' decision criteria", Entrepreneurship Theory and Practice, Vol. 34 No. 4, pp. 705-733.

Mintzberg, H. (1973), "Strategy in three modes", California Management Review, Vol. 16, pp. 44-58.

Mintzberg, H. (1990), "The design school: reconsidering the basic premises of strategic management", Strategic Management Journal, Vol. 11 No. 3, pp. 171-195.

Mintzberg, H. and Waters, J. (1985), "Of strategies deliberate and emergent", Strategic Management Journal, Vol. 6 No. 3, pp. 257-272.

Morris, R. (1994), "Computerized content analysis in management research: a demonstration of advantages and limitations", Journal of Management, Vol. 20 No. 4, pp. 903-931.

Moss, T.W., Short, J.C., Payne, G. and Lumpkin, G.T. (2011), "Dual identities in social ventures: an exploratory study", Entrepreneurship: Theory and Practice, Vol. 35 No. 4, pp. 805-830.

Mulgan, G., Tucker, S., Ali, R. and Sanders, B. (2007), "Social innovation: what it is, why it mattes and how it can be accelerated", Working Paper, Skoll Center for Social Entrepreneurship, University of Oxford, Young Foundation, London, available at: https://youngfoundation.org/wp-content/ uploads/2012/10/Social-Innovation-what-it-is-why-it-matters-how-it-can-be-accelerated-March2007.pdf.

Mulgan, G. (2010), "Measuring social value", Stanford Social Innovation Review, Vol. 8 No. 3, pp. 38-43.

Nunnally, J.C. (1978), Psychometric Theory, 2nd ed., McGraw-Hill, New York, NY.

Olson, E.M., Slater, S.F. and Hult, G.T.M. (2005), "The performance implications of fit among business strategy, marketing organization structure, and strategic behavior", Journal of Marketing, Vol. 69 No. 3, pp. 49-65.

Pearce, J.A. and David, F. (1987), "Corporate mission statements: the bottom line", The Academy of Management Executive Vol. 1 No. 2, pp. 109-115.

Phills, J.A., Deiglmeier, K. and Miller, D.T. (2008), "Rediscovering social innovation”, Stanford Social Innovation Review, Vol. 6 No. 4, pp. 34-43.

Preacher, K.J. and Hayes, A.F. (2008), "Asymptotic and resampling strategies for assessing and comparing indirect effects in multiple mediator models", Behavior Research Methods, Vol. 40 No. 3, pp. 879-891.

Preacher, K.J. and Leonardelli, G.J. (2001), “Calculation for the Sobel test”, available at: http://quantpsy. org/sobel/sobel.htm.

Preacher, K.J., Rucker, D.D. and Hayes, A.F. (2007), “Addressing moderated mediation hypotheses: theory, methods, and prescriptions", Multivariate Behavioral Research, Vol. 42 No. 1, pp. 185-227.

Rajan, A.T., Koserwal, P. and Keerthana, S. (2014), "The Global epicenter of impact investing: an analysis of social venture investments in India”, The Journal of Private Equity, Vol. 17 No. 2, pp. 37-50.

Randjelovic, J., O'Rourke, A.R. and Orsato, R.J. (2003), "The emergence of green venture capital", Business Strategy and the Environment, Vol. 12 No. 4, pp. 240-253.

Renneboog, L., Ter Horst, J. and Zhang, C. (2008), "Socially responsible investments: institutional aspects, performance, and investor behavior", Journal of Banking and Finance, Vol. 32 No. 9, pp. 1723-1742. 
Revelli, C. and Viviani, J.L. (2015), "Financial performance of socially responsible investing (SRI): what have we learned? A meta-analysis", Business Ethics: A European Review, Vol. 24 No. 2, pp. 158-185.

Ridley-Duff, R. (2008), "Social enterprise as a socially rational business", International Journal of Entrepreneurial Behavior and Research, Vol. 14 No. 5, pp. 291-312.

Architectural dimensions of social VC firms

Riffe, D., Lacy, S., Watson, B.R. and Fico, F. (2019), Analyzing Media Messages: Using Quantitative Content Analysis in Research, Routledge, New York.

Rodale, J.I. (1978), The Synonym Finder, Rodale Press, Emmaus, Pennsylvania, PA.

Sacks, M. (2002), "The social structure of new venture funding: stratification and the differential liability of newness", in Lounsbury, M. and Ventresca, M. (Eds), Research in the Sociology of Organizations, JAI Press, Greenwich, Connecticut, CT, pp. 263-294.

Scholtens, B. (2006), "Finance as a driver of corporate social responsibility", Journal of Business Ethics, Vol. 68 No. 1, pp. 19-33.

Schueth, S. (2003), "Socially responsible investing in the United States", Journal of Business Ethics, Vol. 43 No. 3, pp. 189-194.

Short, J.C., Broberg, J.C., Cogliser, C.C. and Brigham, K.H. (2010), "Construct validation using computer-aided text analysis (CATA) an illustration using entrepreneurial orientation", Organizational Research Methods, Vol. 13 No. 2, pp. 320-347.

Slater, S., Olson, E. and Hult, G.T. (2006), "The moderating influence of strategic orientation on the strategy formation capability-performance relationship", Strategic Management Journal, Vol. 27, pp. 1221-1231.

Smith, K.G., Guthrie, J.P. and Chen, M.J. (1989), "Strategy, size and performance”, Organization Studies, Vol. 10 No. 1, pp. 63-81.

Social Investment Forum (2020), Report on US Sustainable, Responsible and Impact Investing Trends 2020, available at: https://www.ussif.org/.

Sorenson, M. (2007), "How smart is smart money? An empirical two-sided matching model of venture capital", Journal of Finance, Vol. 62, pp. 2725-2762.

Thompson, J., Alvy, G. and Lees, A. (2000), "Social entrepreneurship-a new look at the people and the potential”, Management Decision, Vol. 38 No. 5, pp. 328-338.

Tushman, M.L. and Romanelli, B.E. (1985), "Organizational evolution: a metamor-phosis model of convergence and reorientation", in Staw, B.M. and Cummings, L.L. (Eds), Research in Organizational Behavior, JAI, Greenwich, Connecticut, CT, pp. 171-222.

USSIF (2012), "The forum for sustainable and responsible investment", Annual report, available at: https://www.ussif.org/files/Publications/USSIF_2012AnnualReport_F.pdf (accessed on 2012).

Venkatraman, N. (1989), "The concept of fit in strategy research: toward verbal and statistical correspondence", Academy of Management Review, Vol. 14 No. 3, pp. 423-444.

Weber, R.P. (1990), Basic Content Analysis, Sage, Newbury Park, California, CA.

Wickham, P.A. (1997), "Developing a mission for an entrepreneurial venture", Management Decision, Vol. 35 No. 5, pp. 373-381.

Zarutskie, R. (2010), "The role of top management team human capital in venture capital markets: evidence from first-time funds", Journal of Business Venturing, Vol. 25 No. 1, p. 155.

\section{Corresponding author}

Raymond J. Jones can be contacted at: Raymond.jones@sfasu.edu

For instructions on how to order reprints of this article, please visit our website:

www.emeraldgrouppublishing.com/licensing/reprints.htm

Or contact us for further details: permissions@emeraldinsight.com 